\title{
STUDENTS' EVALUATION OF EDUCATION QUALITY IN HUMAN RESOURCE MANAGEMENT AREA: CASE OF PRIVATE CZECH UNIVERSITY
}

\author{
Lucie Vnoučková $^{1}$, Hana Urbancová ${ }^{2}$, Helena Smolová ${ }^{3}$, Julie Šmejkalová ${ }^{4}$ \\ ${ }^{1 ⿴}$ Department of Management, University of Economics and Management, Nárožní 2600/9a, Praha 5, 158 00, Czech Republic, +420 245001488 , \\ lucie.vnouckova@vsem.cz \\ ${ }^{2}$ Department of Management, Faculty of Economics and Management, Czech University of Life Sciences Prague, Czech Republic \\ ${ }^{3}$ Department of Marketing, University of Economics and Management, Czech Republic \\ ${ }^{4}$ Department of Management, University of Economics and Management, Czech Republic
}

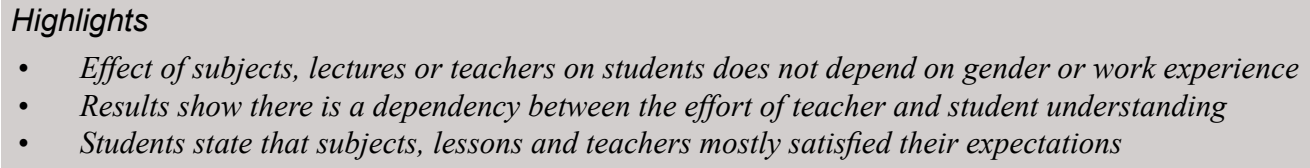

- Effect of subjects, lectures or teachers on students does not depend on gender or work experience

- Results show there is a dependency between the effort of teacher and student understanding

- $\quad$ Students state that subjects, lessons and teachers mostly satisfied their expectations

\section{Abstract}

The quality of education, lessons, subjects and teachers perceived by students is currently often discussed topic regarding strategic management of universities. Assessment of higher education learning outcomes represents internalization of a higher education competition. The aim of the article is to evaluate perception of education quality of lectures, subjects and teachers by university students in the area of human resource management in private Czech university and to identify main approaches to academic staff. The data were collected by quantitative survey by questionnaire data collection $(n=218)$. Students state that subjects, lessons and teachers in the area of human resource management lessons mostly satisfied their expectations (average value between 1.09 and 1.97). The students emphasised that the staff creates positive atmosphere and gives the opportunity to express an opinion which is very important for students at the university. Research outcomes show there is a dependency between the effort of teacher, student understanding and teachers's willingness to give students an opportunity to express an opinion. The paper is extension of conference paper presented on ERIE conference 2016.

\section{Keywords}

Education, learning, student, quality, evaluation, university

Vnoučková L., Urbancová H., Smolová H., Šmejkalová J. (2016) “Students’ Evaluation of Education Quality in Human Resource Management Area: Case of Private Czech University", Journal on Efficiency and Responsibility in Education and Science, Vol. 9, No. 2, pp. 45-51, online ISSN 1803-1617, printed ISSN 2336-2375, doi: 10.7160/eriesj.2016.090203.

\section{Introduction}

The quality of tertiary education is currently often discussed theme at the state, private and public universities. The importance of quality of education grows accordingly to amount of people who want to study. Due to the continuous globalisation is Czech education system confronted with many high standard competitors. While scholars have analyzed global higher education competition, they have largely failed to address how global spaces of equivalence are tied both to coloniality and to competition (Shahjahan and Morgan, 2016).

The results of the study of Thatcher et al. (2016) show that analysis reveals evidence of multiple value adding factors; it emerged that the existence of knowledge, present or generated through blended learning techniques, was a key value adding element. The findings enabled the construction of a universal process model providing a project framework, detailing areas of collaborative efforts and associated recompenses; this included ease in project advancements and a noticeably advanced project outcome. The study highlights these values in terms of individual and organizational learning, originality and quality of outputs (Thatcher et al., 2016).

Shahjahan and Morgan (2016) argue that assessment of higher education learning outcomes represents the mediation and internalization of a higher education competition focused on teaching and learning, which reproduces coloniality by valuing characteristics of the enterprising, globally competitive institution. Ashraf, Osman and Ratan (2016) also state that is crutial to determine the potential influence of education quality in private universities as well as in public universities.

This article aims to evaluate perceptions of education quality of lectures, subjects and teachers by university students in the area of human resource management in selected private Czech university and to identify main approaches to academic staff.

The paper is composed of five sections. The first is Introduction, the second one is Theoretical Background, this followed by a presentation of the methodological approach. Subsequently, an analysis and discussion section comes before the recommendations. Finally, authors conclude the paper and summarize the contributions and limitations of the article, last but not least focus on a future research in this area.

The paper is extension of conference paper presented on ERIE conference 2016 in Prague, Czech University of Life Sciences (Vnoučková et al., 2016). The paper was extended in the results and discussion in parts focused on evaluation of statements of respondents related to subjects, lessons and teachers and also hypotheses related to all three areas are presented. The contribution of the article lies in the emphasis on education quality process in current knowledge economy described by increasing number of public and private universities in the Czech Republic. Accordingly, discussion part was added and the conclusion was extended in compliance with presented results. 


\section{Theoretical Background}

Recently, there has been described in a literature changes in higher education in the field of universities organization and function, due to expansion in the number of students, new systems and structures in universities management and organization and international regulations of higher education. The dominant conception, evident in many countries, has indicated the turn to an audit or corporate culture (see Forrester, 2011; Watts and Robertson 2011) concerned on quality. 'Universities have been reoriented by performance management techniques towards a competitive, performance culture' (Forrester, 2011). HEIS in the global markets have increasingly had to operate under forces of marketization which demand competitiveness, efficiency and consumer satisfaction (Kotler and Armstrong, 2011).

Since the university students are identified as key stakeholders (ACBSP, 2015, AACSB, 2016, IACBE, 2016) or consumers (Zairi, 1995) students' satisfaction should always be considered by the university due to its importance within the educational evaluation, intensive competition among universities, internationalization of higher education institutions and the classification of education as a marketable service (Kwek, Lau and Tan, 2010). Those reasons have prompted the management of the various public and private higher education institutions to pay more attention in assessing the overall students' perceived service quality.

\section{Concept of Quality}

At the European level, quality has always been in the center of attention, being regarded as one of the success factors of the Bologna Declaration (1999). University education, like any other system, is actually focused on concept of quality that is based on the principle of continuous assessment throughout the lifecycle of the system.

Quality is mainly defined by consumers and observers of consumption actions and utility. Quality has been defined in various ways by academics or experts in marketing management. Kotler and Armstrong (2011) states that product quality is one of product characteristics that lies on its ability to satisfy customers' needs. Lassar, Manolis and Winsor (2000) defined service as a set of characteristics that meet the clients' needs, strengthen the links between the organization and them, and enhance the clients' value as well. We can conceptualize quality in different ways and quality serves as a way of differentiating products and services from the point of view of consumers and competitors (Parasuraman, Zeithaml and Berry, 1988).

\section{Service Quality}

Service quality is defined as 'the difference between customers' expectations for service performance prior to the service encounter and their perceptions of the service perceived' (Asubonteng, McCleary and Swan, 1996: 64). While the perceived service quality is defined as 'a global judgment, or attitude, relating to the superiority of the service' (Parasuraman, Zeithaml and Berry, 1988: 16), the core concept of service quality is the disconfirmation of expectations theory (Rowley and Dawes, 1999).

Parasuraman, Zeithaml, and Berry (1988) propose five major dimensions to quality of services: reliability, responsiveness, assurance, tangibles, and empathy. However, the most fundamental idea underlying quality is that it bears on a service's ability to satisfy. When all service quality features such as tangibility, responsiveness, empathy, assurance and reliability are effectively implemented; it may result in enhanced satisfaction of service clients (Grönroos, 1984, Parasuraman, Zeithaml and Berry, 1988; Ismail, Abdullah and Francis, 2009).

\section{Quality Assurance}

The quality assurance [QA] system in HEIS refers to the mechanism by means of which the university grants to students confidence that all the conditions are met to attain the assumed standards. It can be defined as asset of policies, systems and processes directed at the maintenance and enhancement of educational quality. 'With successive government support the university-business partnership ideology has been put into practice. Widening participation has increased in emphasis over recent years, providing key innovations and skills to support business growth. Yet business schools activities in business growth is marginal against other university schools' (Thatcher et al., 2016).

The objective of evaluation is to clarify the steps needed to assess the processes and outcomes of a program or organization. An effective evaluation is a dynamic tool that should be updated on an ongoing basis to reflect any changes and priorities over time. Internal evaluation can be used for program planning by highlighting goals, clarifying measurable objectives, and linking activities with intended outcomes (Megnounif, Kherbouche and Chermitti, 2013). The choice of a quality approach is imposed when the aim is to ensure the quality assurance of the product and at the same time to increase customer satisfaction.

\section{Students as Consumers of Higher Education}

Student satisfaction is a complex construct with various antecedents and these are not the same as in the actual customer satisfaction models. Customer satisfaction involves customer expectation of the service delivery, actual delivery of the customer experience, including under or over-fulfillment. If expectations are exceeded, positive results are given, while negative results are given when customer experience is poorer than expected (Kotler and Armstrong, 2011). Customer satisfaction also affects economic returns, i.e. profitability, market share, and return on investment (Anderson, Fornell and Lehmann, 1994).

Students' satisfaction could be presented as overall response not only to the learning experience of a student but also Student satisfaction is a changing construct in the Higher Education environment due to repeated interactions (Elliott and Shin, 2002). 'Focusing on student satisfaction not only enables universities to re-engineer their organizations to adapt to student needs, but also allows them to develop a system for continuous monitoring of how effectively they meet or exceed student needs' (Elliott and Shin, 2002: 197).

Education quality, according to Cheng (2003) is the character of an input, process and output of the education system that satisfy both internal and external stakeholders by meeting their explicit and implicit expectation.

The national QA evaluation methodology (which is closely following the Guidelines for Quality Assurance in the European HE Area), includes indicators regarding students' satisfaction: Though satisfied with the academic programs, students may be disappointed in other aspects, such as career counseling or 
material conditions (Kotler and Fox, 1995). It is less expensive to maintain a present customer than to recruit a new one (Babin and Griffin, 1998).

Student's satisfaction survey could bring unique data and sources in identifying problem areas within the university, and in integrating information and data from students in a broader agenda mediated through institution. Student perception of studies also relate to an important goal of education, that is to develop student learning and engagement (Delaney, 1997). 'The ability to predict what university course a student may select has important quality assurance and economic imperatives. The capacity to determine future course load and student interests provides for increased accuracy in the allocation of resources including curriculum and learning support and career counselling services. The findings suggest that a students' grade point average relative to the grades of the courses they are considering for enrolment was the most important factor in determining future course selections' (Ognjanovic, Gasevic and Dawson, 2016).

Taking into account the different views, definitions and dimensions of quality are different in their measurement standards. Most researchers on service quality use customer satisfaction as the indicator for quality. The better the quality is, the more satisfied the customers should be. Students' satisfaction survey - identification of the students' satisfaction level concerning a broad range of aspects - it is a relatively new practice. Therefore it is analyzed in this paper.

\section{Materials and Methods}

This paper was prepared using a method of an analysis of secondary and primary resources, knowledge synthesis, induction, deduction and comparison. As part of secondary resources, scientific monographs and articles dealing with the theme were analysed. At the same time, websites of companies that are actively dealing with the issue were analysed. The primary data were obtained by conducting a quantitative research, through data collection using questionnaires.

The survey was carried out using students and academic staff. The student data set comprised in total 218 students. The evaluated subjects were Human Resource Management, Human Resource Development, Communication, Psychology in Human Resources, Leadership, Managerial Decision Making and Managerial Skills. Total 11 teachers were leading those subjects for evaluated students. Only students who passed the whole education and evaluation process of mentioned selected subjects in the area of human resources were part of the survey.

The respondents were structured as follows:

- $\quad$ Student category: 65 (30\%) men, 153 (70\%) women;

- Student professional experience: 128 (58.5\%) works in area of study, 89 (41.5\%) does not work;

- Student future intention to work in the area of study: 146 (67\%) plan to works in area of studied subjects, $12(0.5 \%)$ does not plan to work in area of studied subjects and the rest does not know.

The data collection instrument included questions to measure the activities of education in studied university. The questions were designed based on theories (see theoretical background) and similar researches.
The questionnaire addressed three main areas (other than identification questions). Those were lessons and their content, the course/subject and structure and usefulness and teachers quality.

Respondents' reactions to target statements and their attitudes to the given matter were restricted by offering a set of several statements. The extremes of the five-point scale represented bipolar concepts of the evaluation dimension. All the questions were measured in a Likert type scale with verbal anchors in 1 (strongly disagree) and 5 (strongly agree) or, provided it was not possible to favour either of the sides, selected a median, neutral value (the median value was characterized by number 3 ). The scale permitted not only the specification of respondents' attitudes, but also their intensity.

The data were evaluated using the tools of descriptive statistics (average, modus, median and standard deviation including absolute and relative frequency) and two dimensional statistics was used using Pearson's correlation coefficient to reveal relations between searched attributes. To evaluate the results IBM SPSS statistics were used.

\section{Results}

The objective of this chapter is to evaluate the results obtained from the primary survey. The results of the quantitative research have been statistically evaluated and recommendations have been formulated upon this basis. As the paper focuses on quality evaluation of three areas (subjects, courses and teachers) in human resource management education, the chapter presents results gained in these areas.

Firstly, students' evaluation of subject is presented. Bellow in the Table 1 the results show students perception of different attributes of subjects. Most of the attributes are evaluated positively (on the scale where 1 is the best and 5 is the worst). Modus and median values are almost always 1 , except for difficulty of the studied subjects. Students evaluated the difficulty compare to other studied subjects. The most difficult for them is economics and related subjects. On the other hand, management and human resource management are usually evaluated as in the middle of difficultness. The average value of all attributes is 1.79 . The perception of quality of lecture is on relatively high level. Additionally, standard deviation maximum value is 0.97 .

\begin{tabular}{|l|c|c|c|c|}
\hline Subject & AVG & MOD & MED & STD \\
\hline filled expectations & 1.52 & 1 & 1 & 0.80 \\
\hline is difficult & 2.97 & 3 & 2.5 & 0.97 \\
\hline is beneficial and valuable & 1.44 & 1 & 1 & 0.65 \\
\hline is connected with praxis & 1.61 & 1 & 1 & 0.82 \\
\hline is adequately placed is study program & 1.47 & 1 & 1 & 0.70 \\
\hline requirements for exam are adequate & 1.70 & 1 & 1 & 0.83 \\
\hline AVG & 1.79 & - & - & - \\
\hline
\end{tabular}

Tab. 1: Statements of respondents related to subjects

As it is possible to see in Table 1, the subjects studied in the area of human resource management mostly filled the expectations (average value 1.52, modus and median 1), the subjects studied are valuable (average 1.44, modus and median also 1) and connected with praxis (average 1.66, modus and median 1). As the data were deeply analysed and the students questioned, they prefer subjects oriented on praxis. The connection of lessons with case studies and projects is evaluated as the best between the surveyed students. They also value experts from companies for workshops and seminars. 
Evaluated attributes questioned students in the way of their readiness for passing the subject. Again, most of the respondents evaluated it positively, that they had good overall knowledge to be able to handle the learning goals and outcomes. Students also stated that requirements for exams are adequate (average 1.70, modus and median 1). Therefore it is possible to assume that the subjects are well placed in study plans and the content of the subjects is manageable for students who are able to prepare themselves for the exams.

The second area studied by the survey is lectures. The main results are placed in the Table 2 . Similarly to the first evaluated area, lectures are evaluated well by the students (average value is 1.27 , modus and median are 1). The results are even better than in the area of lessons.

\begin{tabular}{|l|c|c|c|c|}
\hline Lecture & AVG & MOD & MED & STD \\
\hline Lectures are adequate & 1.24 & 1 & 1 & 0.50 \\
\hline Style of explanation is adequate & 1.27 & 1 & 1 & 0.56 \\
\hline Explanation is understandable & 1.19 & 1 & 1 & 0.44 \\
\hline Tempo suits me & 1.27 & 1 & 1 & 0.53 \\
\hline The way of explanation suits me & 1.39 & 1 & 1 & 0.65 \\
\hline AVG & 1.27 & - & - & - \\
\hline
\end{tabular}

\section{Tab. 2: Statements of respondents related to lectures}

Surveyed students perceive lectures as adequate (average 1.24, modus and median 1), style of explanation seems to be adequate (average 1.27, modus and median 1). Students perceive explanation as understandable, with suitable tempo of discussed topics and way of teaching.

The third area surveyed by questionnaires is lecturers. Students evaluated different attributes related to their teacher and his/her teaching techniques. The results are shown in Table 3 . As it is possible to see in the table, students evaluated teachers the best of all studied areas (average value is 1.24, modus and median always 1).

\begin{tabular}{|l|c|c|c|c|}
\hline Teacher & AVG & MOD & MED & STD \\
\hline is an expert & 1.21 & 1 & 1 & 0.53 \\
\hline uses modern teaching techniques & 1.34 & 1 & 1 & 0.68 \\
\hline uses modern technologies & 1.37 & 1 & 1 & 0.69 \\
\hline motivates to learn & 1.35 & 1 & 1 & 0.67 \\
\hline is able to attract & 1.20 & 1 & 1 & 0.54 \\
\hline creates positive atmosphere & 1.09 & 1 & 1 & 0.37 \\
\hline adequately explains & 1.17 & 1 & 1 & 0.45 \\
\hline connects theory and praxis & 1.31 & 1 & 1 & 0.65 \\
\hline places attention on practicing & 1.39 & 1 & 1 & 0.71 \\
\hline cares about students understanding & 1.13 & 1 & 1 & 0.47 \\
\hline $\begin{array}{l}\text { gives the opportunity to express } \\
\text { opinion }\end{array}$ & 1.09 & 1 & 1 & 0.41 \\
\hline AVG & 1.24 & - & - & - \\
\hline
\end{tabular}

Tab. 3: Statements of respondents related to teachers

The area of lecturers was studied from more standpoints. Attributes focus on the personality of the teacher, his/her abilities, skills and competencies related to positive and stimulus work with students and also their abilities to connect the theory with praxis.

Students perceive their teacher as an expert (average 1.21, modus and median 1). Best of all searched attributes students evaluate the opportunity to express their opinion and ability of teacher to create positive atmosphere (in both cases average value is 1.09). Mentioned attributes are strengths of teachers surveyed in the research. Also positive is the result that teacher cares about students understanding (average 1.13) and can adequately explain theory and related areas (average 1.17).

It is possible to summarize that quality evaluation of teachers shows very good results. Students perceive quality teachers skills, abilities and knowledge. Surveyed students evaluate positively also connection with praxis during the lessons and high level of explanation and discussion.

To see, whether there are some relations between searched attributes, correlation analysis was used to evaluate the results. The statistically significant results are shown in the Tables 4, 5 and 6. Interesting finding is that effect of subjects, lectures or teachers on students does not depend on gender or work experience, neither on plans for future work area.

\begin{tabular}{|l|c|c|}
\hline Hypothesis & $\begin{array}{c}\text { Pearsons } \\
\text { correlation }\end{array}$ & p-value \\
\hline $\begin{array}{l}\text { Subject is beneficial and valuable - is } \\
\text { connected with praxis }\end{array}$ & 0.348 & 0.00 \\
\hline $\begin{array}{l}\text { Subject is beneficial and valuable - filled } \\
\text { expectations }\end{array}$ & 0.449 & 0.02 \\
\hline $\begin{array}{l}\text { Adequately placed is study program - filled } \\
\text { expectations }\end{array}$ & 0.308 & 0.04 \\
\hline
\end{tabular}

Tab. 4: Hypothesis related to subjects

The analysis of the area of subjects revealed three statistically significant correlations. Students perceive subjects as beneficial and valuable when they are connect with praxis and when they filled their expectations. That means students come to university with usually clear picture about subjects they will and want to study and they want them to be connected with praxis to fill their expectations. It is necessary to mention that half of the surveyed students were part time students. Part time study is specific form of study; students already work full-time for some time and they have clear expectations about their studies and how they should fit into their current or future job position. The correlation analysis confirmed this. But also regular full time students perceive it in the same way. They also want their subjects to be connected with praxis to fill their expectations.

Students' expectations seem to be quite important in perception of quality education by students. The correlation analysis finds another significant relation connect with expectations. It is adequate structure of study program. The surveyed students perceive subjects as filling their expectations when they are adequately placed in study program. That means the continuity of study program and subject is very important and evaluated by students. Only when subjects properly follow logical structure it is perceived as filling students expectations.

The Table 5 bellow presents the results of correlation analysis focused on the lectures and their quality evaluation. 


\begin{tabular}{|l|c|c|}
\hline Hypothesis & $\begin{array}{c}\text { Pearsons } \\
\text { correlation }\end{array}$ & p-value \\
\hline $\begin{array}{l}\text { Suitable way of explanation - style of } \\
\text { explanation is adequate }\end{array}$ & 0.528 & 0.02 \\
\hline $\begin{array}{l}\text { Suitable way of explanation - tempo is } \\
\text { suitable }\end{array}$ & 0.413 & 0.04 \\
\hline $\begin{array}{l}\text { Suitable way of explanation - explanation is } \\
\text { understandable }\end{array}$ & 0.367 & 0.01 \\
\hline $\begin{array}{l}\text { Explanation is understandable - tempo is } \\
\text { suitable }\end{array}$ & 0.572 & 0.05 \\
\hline $\begin{array}{l}\text { Explanation is understandable - style of } \\
\text { explanation is adequate }\end{array}$ & 0.572 & 0.02 \\
\hline $\begin{array}{l}\text { Lectures are adequate - style of explanation } \\
\text { is adequate }\end{array}$ & 0.536 & 0.02 \\
\hline
\end{tabular}

Tab. 5: Hypothesis related to lectures

In the area of lectures students perceive way of explanation as suitable when it is adequate, tempo is suitable and explanation is understandable. Those areas are straight connected and there are close relations between them. Similarly, students see explanation as understandable when tempo is suitable for them and style of explanations is adequate. Also, the analysis found relation between adequate style of explanation and perception of lectures as adequate.

It is possible to conclude that the whole area of lectures is inter-correlated. Almost all attributes are connected. Surveyed students perceive lecture as adequate when the explanation, style and tempo is suitable and understandable. That means it is necessary to use all these techniques and focus on tempo, style and comprehensibility to maintain students attention and satisfaction with lectures.

Finally, bellow in table 6 the correlation analysis of quality perception of teachers by surveyed students is presented.

\begin{tabular}{|l|c|c|}
\hline Hypothesis & $\begin{array}{c}\text { Pearsons } \\
\text { correlation }\end{array}$ & p-value \\
\hline $\begin{array}{l}\text { Cares about students understanding - } \\
\text { opportunity to express opinion }\end{array}$ & 0.508 & 0.00 \\
\hline $\begin{array}{l}\text { Cares about students understanding - } \\
\text { adequately explains }\end{array}$ & 0.507 & 0.02 \\
\hline $\begin{array}{l}\text { Place attention on practicing - connects } \\
\text { theory and praxis }\end{array}$ & 0.406 & 0.05 \\
\hline Attention on practicing - able to attract & 0.443 & 0.02 \\
\hline Attention on practicing - motivates to learn & 0.522 & 0.02 \\
\hline $\begin{array}{l}\text { Attention on practicing - uses modern } \\
\text { teaching techniques }\end{array}$ & 0.438 & 0.04 \\
\hline Motivates to learn - is an expert & 0.433 & 0.01 \\
\hline $\begin{array}{l}\text { Uses modern technologies - uses modern } \\
\text { teaching techniques }\end{array}$ & 0.716 & 0.00 \\
\hline
\end{tabular}

Tab. 6: Hypothesis related to teachers

Correlation analysis revealed relations between the effort of teacher about student understanding and his/her willingness to give students an opportunity to express their opinion. Similarly, a care of a teacher about students positively correlates with his/her explanation in the course theory. That means students positively perceive when a teacher shows respect to the students. They seems better understand the theory and they are not afraid to ask questions.

Another correlation was found between connection of theory and practice while teacher is oriented also on practice. This relation is no surprise, but students can better understand theory, when it is shown on examples.
Attention on practicing also correlates with students' attraction, motivation for learning and use of modern teaching techniques. This result therefore confirms that practicing in seminars and workshops or even as a part of theoretical lecture leads to higher motivation of students and their attraction.

Students perceive their teacher as an expert when he/she is able to motivate them to learn. And vice versa, an expert in the field motivates students to learn. Consequently it is necessary to employ specialists in order to gain students attraction and motivation to learn.

The last strong correlation was found between use of modern technologies and modern teaching techniques by a teacher. Students perceive a teacher to be expert in modern education techniques, as he/she is able to use also new technologies (it is sometimes interconnected). As students are these days straight connected to technique (tablets, PC, mobile technologies etc.), they expect also a teacher to use them and use the opportunities which they offer also to education.

\section{Discussion}

To summarize, students evaluate the best quality teachers who can connect theory and praxis and cares about students' needs. The best evaluated are also teachers with ability to work with new teaching techniques and technologies. Sarabdeen (2013) according to her results states that understanding of learning styles helps the educators and the trainers to deliver relevant materials in a learning/training process. This creates an enthusiasm and motivation among the learners to learn and practice what they have learned. For a successful learning process is very important selection of teaching techniques and technologies. As Keengwe and Georgina (2011) states, the educator should have the understanding of different learners and should be flexible to adapt the trainees' needs. The survey of Borges and Stiubiener (2015) shows, that the information and communication technologies nowadays used in educational process have become increasingly present in education, either as support for classroom learning or in distance learning. Together they support the online systems in education. They also state that the online systems are used for better student-teacher communication and especially for providing instructional materials, activities, assessments and other resources to provide collaborative activities. According to both Sarabdeen (2013) and Cheng (2003) it is very important to correctly combine the selection of the teaching techniques (for example role playing, simulation in the lecture/seminars) and technologies. Well placed combinations of methods will have influence to the results of educational process quality and satisfaction of students and academic staff.

\section{Conclusion}

Presented paper analysed and assessed the education quality of subjects oriented to human resources at the private university. The paper focused on perception of education quality by students and teachers. The results show that students in general find economics more difficult compared to management and human resource management and the perception of quality of lecture is at relatively high level at the university. The students state that subjects studied in the area of human resource management lessons mostly satisfied their expectations, the subjects studied are valuable and connected with practice, the requirements for exams are adequate (average value between 1.44 and 1.97). The results from assessment of the lectures are even better than in the area of lessons. The average value in every evaluating 
criterion was from 1.19 to 1.39 . Students assessed the academic staff relatively positive, they emphasised that the staff creates positive atmosphere and gives the opportunity to express an opinion which is very important for students at the university.

Research outcomes identified that the effect of subjects, lectures or teachers on students does not depend on gender or work experience, neither on plans for future work area. On the other hand there is a dependency between the effort of teacher, student understanding and teachers's willingness to give students an opportunity to express an opinion.

The theoretical contribution of the article lies in the emphasis on education quality process in current knowledge economy described by increasing of the number of public and private universities in the Czech Republic. The practical contribution of this article lies in presenting the actual results from evaluating process at the private university. The results are important base for assessment process of academic staff and preparation of the new study program.

Besides this study there are several promising directions for further research. It would be useful to include the influence of the students' attendance on the seminars and lectures on successfulness in exams.

\section{Acknowledgements}

This contribution is a follow-up to the project of University of Economics and Management.

\section{References}

AACSB (2016) 'About AACSB/Accredited Institutions', Advancing Quality Management Education Worldwide, [Online]. Available: http://www.aacsb.edu/about/default.asp [24 Feb 2016].

ACBSP (2015) 'A Process Book For Institutions Seeking Initial $\&$ Reaffirmation of Accreditation', The Accreditation Council for Business Schools and Programs, [Online]. Available: http://c.ymcdn.com/sites/www.acbsp.org/resource/collection/ EB5F486D-441E-4156-9991-00D6C3A44ED1/Accreditation Process_Manual_for_Baccalaureate_and_Graduate_Degree_ Programs.pdf [24 Feb 2016].

Anderson, E. W., Fornell, C., Lehmann, D. R. (1994) 'Customer Satisfaction, Market Share, and Profitability: Findings From Sweden', Journal of Marketing, Vol. 58, No. 3, pp. 53-66. DOI $10.2307 / 1252310$.

Ashraf, M. A., Osman, A. Z. R., Ratan, S. R. A. (2016) 'Determinants of quality education in private universities from student perspectives: A case study in Bangladesh', Quality Assurance in Education, Vol. 24, No. 1, pp. 123-138. DOI 10.1108/qae-09-2013-0040.

Asubonteng, P., McCleary, K. J., Swan, J. E. (1996) 'SERVQUAL revisited: A critical review of service quality', The Journal of Services Marketing, Vol. 10, No. 6, pp. 66-81. DOI 10.1108/08876049610148602.

Babin, B. J., Griffin, M. (1998) 'The Nature of Satisfaction: An Updated Examination and Analysis', Journal of Business Research, Vol. 41, pp. 127-136. DOI 10.1016/s01482963(97)00001-5.

Borges, G., Stiubiener, I. (2015) 'Recommending learning objects based on utility and learning style', Proceedings Frontiers in Education Conference, FIE. Spain: Melia Castilla Hotel and Convention Center Madrid.

Cheng, Y. C. (2003) 'Quality assurance in education: Internal, interface and future', Quality Assurance in Education Journal, Vol. 11, No. 4, pp. 202-213. DOI 10.1108/09684880310501386. Delaney, M. A. (1997) 'Quality Assessment of Professional Degree Programs', Research in Higher Education, Vol. 38, No. 2, pp. 241-264. DOI 10.1023/a:1024989805110.

Elliott, K. M., Shin, D. (2002) 'Student Satisfaction: an alternative approach to assessing this important concept', Journal of Higher Education Policy and Management, Vol. 24, No. 2, pp. 199-209. DOI 10.1080/1360080022000013518.

European Commission (1999) Bologna declaration. Italy: Bologna.

Forrester, G. (2011) 'Performance management in education: milestone or millstone?', Management in Education, Vol. 25, pp. 5-9. DOI 10.1177/0892020610383902.

Grönroos, C. (1984) 'A Service Quality Model and Its Marketing Implications', European Journal of Marketing, Vol. 18. No. 4, pp. 36-45. DOI 10.1108/eum0000000004784.

IACBE (2016) 'Defining Academic Quality', International Assembly for Collegiate Business Education, [Online]. Available: http://iacbe.org/qa-academic-quality.asp [25 Feb 2016].

Ismail, A., Abdullah, M. M. B., Francis, S. K. (2009) 'Exploring the Relationships among Service Quality Features, Perceived Value and Customer Satisfaction', Journal of Industrial Engineering and Management, Vol. 2, No. 1, pp. 230-250. DOI 10.3926/jiem.2009.v2n1.p230-250.

Keengwe, J., Georgina, D. (2011) 'The Digital Course Training Workshop for Online Learning and Teaching', Education and Information Technology, Vol. 17, No. 4., pp. 365-379. DOI 10.1007/s10639-011-9164-x.

Kotler, P., Armstrong, G. (2011) 'Principles of Marketing', 14th edition, Prentice Hall: Pearson Education.

Kotler, P., Fox, K. (1995) 'Strategic Marketing for Educational Institutions', 2nd edition, Englewood Cliffs, N.J.: Prentice-Hall. Kwek, C., Lau. T., Tan, H. (2010) 'Education Quality Process Model and Its Influence on Students' Perceived Service Quality', International Journal of Business and Management, Vol. 5, No. 8, pp. 154-165. DOI 10.5539/ijbm.v5n8p154.

Lassar, W. M., Manolis, C., Winsor, R. D. (2000) 'Service Quality Perspectives \& Satisfaction in Private Banking', Journal of Service marketing, Vol. 14, No. 3, pp. 244-271. DOI 10.1108/02652320010349067.

Megnounif, A., Kherbouche, A., Chermitti, N. (2013) 'Contribution to the Quality Assessment in Higher Education: The Case Study of the Faculty of Technology, Tlemcen, Algeria', Social and Behavioral Sciences, Vol. 102, No. 22, pp. 276 - 287. DOI 10.1016/j.sbspro.2013.10.742.

Ognjanovic, I., Gasevic, D., Dawson, S. (2016) ' Using institutional data to predict student course selections in higher education', Internet and Higher Education, Vol. 29, pp. 49-62. DOI 10.1016/j.iheduc.2015.12.002.

Parasuraman, A., Zeithaml, V., Berry, L. L. (1988) 'SERVQUAL: A Multiple-Item Scale for Measuring Customer Perceptions of Service Quality', Journal of Retailing, Vol. 64, No. 1, pp. 12-40. Rowley, J., Dawes, J. (1999) 'Customer loyalty - a relevant concept for libraries? ', Library Management, Vol. 20, No. 6, pp. 345 - 351. DOI 10.1108/01435129910280474.

Sarabdeen, J. (2013) 'Learning Styles and Training Methods', Communications of the IBIMA, p. 9. DOI 10.5171/2013.311167. Shahjahan, R.A., Morgan, C. (2016) 'Global competition, coloniality, and the geopolitics of knowledge in higher education', British Journal of Sociology of Education, Vol. 37, No. 1, pp. 92 - 109. DOI 10.1080/01425692.2015.1095635.

Thatcher, I., Alao, H., Brown, C., I., Choudhary, S. (2016) 
'Enriching the values of micro and small business research projects: co-creation service provision as perceived by academic, business and student', Studies in Higher Education, Vol. 41, No. 3, pp. 560-581. DOI 10.1080/03075079.2014.942273.

Vnoučková, L., Urbancová, H., Smolová, H., Šmejkalová, J. (2016) 'Perception of education quality in subjects related to human resources by university students', In 13th International Conference Efficiency and Responsibility in Education. Prague: Czech University of Life Sciences, pp. 96-103.

Watts, J., Robertson, N. (2011) 'Burnout in university teaching staff: A systematic literature review', Educational Research, Vol. 53, No. 1, pp. 33-50. DOI 10.1080/00131881.2011.552235. Zairi, M. (1995) 'Total quality education for superior performance', Training for Quality, Vol. 3, No. 1, pp. 29-35. DOI 10.1108/09684879510082238. 